\title{
2015 Groundwater Radiological Monitoring Results Associated with the Advanced Test Reactor Complex Cold Waste Ponds
}

Mike Lewis

February 2016

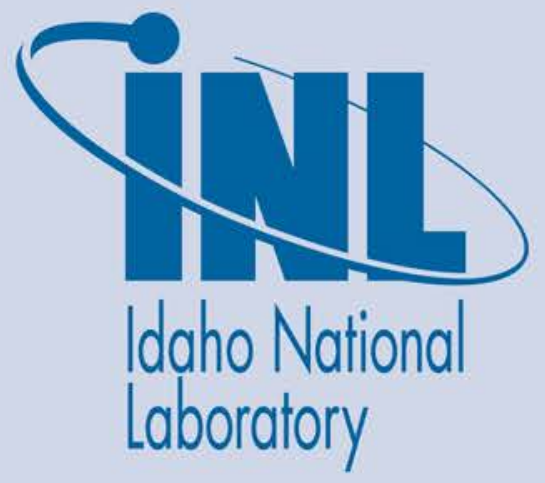

The INL is a U.S. Department of Energy National Laboratory operated by Battelle Energy Alliance 


\title{
2015 Groundwater Radiological Monitoring Results Associated with the Advanced Test Reactor Complex Cold Waste Ponds
}

\author{
Mike Lewis
}

February 2016

Idaho National Laboratory
Idaho Falls, Idaho 83415

http://www.inl.gov

Prepared for the

U.S. Department of Energy

Office of Nuclear Energy

Under DOE Idaho Operations Office

Contract DE-AC07-05ID14517 


\section{Groundwater Radiological Monitoring Results} Associated with the Advanced Test Reactor Complex Cold Waste Ponds 



\begin{abstract}
This report summarizes radiological monitoring results from groundwater wells associated with the Idaho National Laboratory Site's Advanced Test Reactor Complex Cold Waste Ponds Reuse Permit (I-161-02). All radiological monitoring is performed to fulfill Department of Energy requirements under the Atomic Energy Act.
\end{abstract}




\section{CONTENTS}

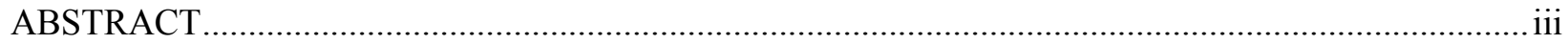

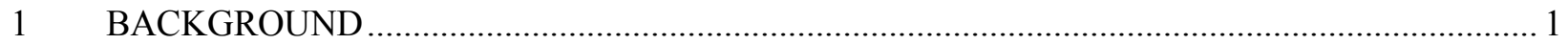

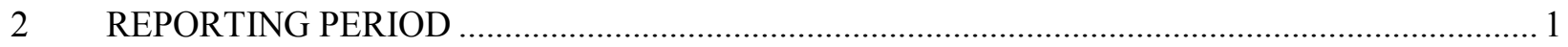

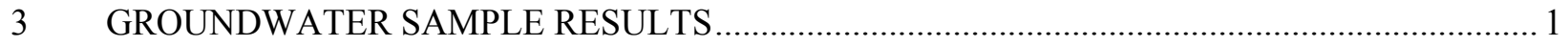

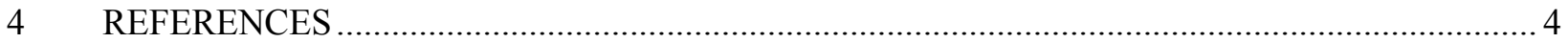

\section{TABLE}

Table 1. Gross alpha, gross beta, and tritium results from samples collected in May and October 2015 from the Advanced Test Reactor Complex Cold Waste Ponds Reuse Permit monitoring wells. 


\section{Groundwater Radiological Monitoring Results Associated with the Advanced Test Reactor Complex Cold Waste Ponds}

\section{BACKGROUND}

The radiological information presented in this report is provided based upon an agreement between the Idaho Department of Environmental Quality and the U.S. Department of Energy Idaho Operations Office. This report fulfills the terms of agreement documented in the current Reuse Permit (I-161-02) for the Idaho National Laboratory Site's Advanced Test Reactor Complex Cold Waste Ponds (CWP). The Reuse Permit was issued on November 20, 2014 (Neher 2015).

Section 2, Additional Facility Information, of the Reuse Permit states "The Permittee agrees to provide to DEQ the results of ground water radiological monitoring with respect to the INL ATR Complex Cold Waste Ponds that is performed to fulfill Department of Energy requirements under the Atomic Energy Act." The Permittee agrees to provide the results at the same time as the annual report.

\section{REPORTING PERIOD}

For the ATR Complex CWP, the Reuse Permit reporting year runs from November 1, 2014-October 31, 2015. Section 5.2.2 of the Reuse Permit requires groundwater samples to be collected twice annually in April or May and September or October.

\section{GROUNDWATER SAMPLE RESULTS}

Samples were collected to satisfy the release objectives of DOE Order 458.1, "Radiation Protection of the Public and the Environment" and addressed within the Environmental Management System required by DOE Order 436.1, "Departmental Sustainability".

Groundwater samples for radiological parameters were collected from aquifer wells USGS-098, USGS-065, TRA-08, USGS-076, Middle-1823, and USGS-058 in May and October 2015. A field duplicate sample was collected from Middle-1823 on October 13, 2015. Samples were analyzed by gamma spectrometry, and for gross alpha, gross beta, tritium, and strontium-90.

Only gross alpha, gross beta, and tritium were positively detected in the May and/or October samples (Table 2). Positive detections are considered measurements exceeding the instrument's minimum detection level and greater than two times the uncertainty. 
Table 1. Gross alpha, gross beta, and tritium results from samples collected in May and October 2015 from the Advanced Test Reactor Complex Cold Waste Ponds Reuse Permit monitoring wells.

\begin{tabular}{|c|c|c|c|}
\hline Monitoring Well & Sample Date & Parameter & $\begin{array}{c}\text { Sample Result } \\
(\mathrm{pCi} / \mathrm{L})\end{array}$ \\
\hline \multirow[t]{6}{*}{ USGS-098 } & $05 / 06 / 15$ & Gross Alpha & $\mathrm{ND}^{\mathrm{a}}$ \\
\hline & & Gross Beta & $5.35( \pm 0.886)^{b}$ \\
\hline & & Tritium & ND \\
\hline & $10 / 13 / 15$ & Gross Alpha & ND \\
\hline & & Gross Beta & $2.95( \pm 0.401)$ \\
\hline & & Tritium & ND \\
\hline \multirow[t]{6}{*}{ USGS-065 } & $05 / 07 / 15$ & Gross Alpha & $3.21( \pm 1.1)$ \\
\hline & & Gross Beta & $2.17( \pm 0.703)$ \\
\hline & & Tritium & $2,770( \pm 314)$ \\
\hline & $10 / 14 / 15$ & Gross Alpha & ND \\
\hline & & Gross Beta & $3.3( \pm 0.359)$ \\
\hline & & Tritium & $3,340( \pm 371)$ \\
\hline \multirow[t]{6}{*}{ TRA-08 } & $05 / 07 / 15$ & Gross Alpha & ND \\
\hline & & Gross Beta & ND \\
\hline & & Tritium & $1,360( \pm 185)$ \\
\hline & $10 / 14 / 15$ & Gross Alpha & ND \\
\hline & & Gross Beta & $3.01( \pm 0.782)$ \\
\hline & & Tritium & $1,430( \pm 197)$ \\
\hline \multirow[t]{6}{*}{ USGS-076 } & $05 / 06 / 15$ & Gross Alpha & ND \\
\hline & & Gross Beta & ND \\
\hline & & Tritium & $561( \pm 125)$ \\
\hline & $10 / 13 / 15$ & Gross Alpha & $1.31( \pm 0.332) \mathrm{ND}$ \\
\hline & & Gross Beta & $17.2( \pm 0.632)$ \\
\hline & & Tritium & $463( \pm 0.124)$ \\
\hline \multirow[t]{6}{*}{ Middle-1823 } & $05 / 06 / 15$ & Gross Alpha & ND \\
\hline & & Gross Beta & ND \\
\hline & & Tritium & $771( \pm 138)$ \\
\hline & $10 / 13 / 15$ & Gross Alpha & $\begin{array}{l}\mathrm{ND} \\
\mathrm{ND}^{\mathrm{c}}\end{array}$ \\
\hline & & Gross Beta & $\begin{array}{c}2.49( \pm 0.43) \\
1.95( \pm 0.497)^{\mathrm{c}}\end{array}$ \\
\hline & & Tritium & $\begin{array}{c}856( \pm 147) \\
1,110( \pm 0.170)^{\mathrm{c}}\end{array}$ \\
\hline \multirow[t]{3}{*}{ USGS-058 } & $05 / 07 / 15$ & Gross Alpha & $\mathrm{ND}$ \\
\hline & & Gross Beta & ND \\
\hline & & Tritium & $889( \pm 147)$ \\
\hline
\end{tabular}




\begin{tabular}{|c|c|c|c|}
\hline Monitoring Well & Sample Date & Parameter & $\begin{array}{c}\text { Sample Result } \\
\text { (pCi/L) }\end{array}$ \\
\hline & $10 / 14 / 15$ & Gross Alpha & ND \\
\hline & & Gross Beta & $3.04( \pm 0.845)$ \\
\hline & & Tritium & $796( \pm 147)$ \\
\hline \multicolumn{4}{|c|}{$\begin{array}{ll}\text { a. ND - Not detected. } \\
\text { b. One sigma uncertainty shown in parentheses. } \\
\text { c. Analytical result from field duplicate sample collected on October 13, } 2015 \text { from well } \\
\text { Middle-1823. }\end{array}$} \\
\hline
\end{tabular}




\section{REFERENCES}

42 USC § 2011-2259, 1954, “Atomic Energy Act of 1954,” United States Code.

DOE Order 436.1, 2011, "Departmental Sustainability,” U.S. Department of Energy, May 2, 2011.

DOE Order 458.1, 2011, "Radiation Protection of the Public and the Environment," U.S. Department of Energy, January 15, 2013.

Neher, E., DEQ, to R. Boston, DOE-ID, November 20, 2014, "I-161-02 INL ATR Cold Waste Ponds, Final Permit," CCN 234522. 